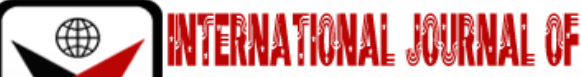 \\ בmRक
}

ISSN 2278-0211 (Online)

\section{Teachers' Use of Computers in Teaching and Learning in Public Secondary Schools in Arusha City Council, Tanzania}

\author{
Hellena D. Mchalo \\ Master Candidate, Departmentof Curriculum and Instruction, \\ Mwenge Catholic University, Tanzania \\ Gadi Koda \\ Lecturer, Department of Educational Psychology, Evaluation, Measurement and Curriculum \\ Studies, Mwenge Catholic University, Tanzania \\ Timothy Mandila \\ Lecturer, Department of Educational Psychology, Evaluation, Measurement and Curriculum \\ Studies, Mwenge Catholic University, Tanzania
}

\begin{abstract}
:
This study investigated the extent to which teachers use computers in teaching and learning in public secondary schools in Arusha city council, Tanzania. Rogers' Diffusion of Innovation theory guided the study. Convergent parallel design under mixed research approach was adopted. Purposive and stratified simple random technique were used to obtain 110 respondents where by 100 were teachers and 10 were heads of schools. Instruments of data collection were questionnaires, structured Interview guide and observation guide. Quantitative data were analyzed descriptively usingmean, standard deviation, frequency tables and percentages, while qualitative data were thematically analyzed. Research ethics were observed whereby sources of information and anonymity of respondents were strictly adhered. The study found that, computers, electrical power and related programs were available in public secondary schools, but technical support as well as supportive and auxiliary infrastructures were found to be averagely available or not available in other schools. Findings gathered that, teachers to a small extent use computers in planning for teaching, lesson preparation, lesson presentation, assessment and evaluation as well as in communication and information sharing. Nevertheless, to a moderate extent teachers use computers for record keeping. Findings exposed that, teachers less often use computers in assessment and evaluation and in record keeping but rarely in planning for teaching, lesson preparation, lesson presentation as well as in communication and information sharing. The study recommended the government to ensure trainings of teachers to enhance their skills in using computer in teaching and learning.
\end{abstract}

Keywords: Computers, teaching, learning, public secondary schools

\section{Introduction}

Today's students are the first generation of young people to have lived their entire lives in a society shaped by computer technology, and unlike previous generations, they will never experience a world without it (Kavagi, 2015). For this new generation of teachers and students technology is an essential and integral part of everyday life (Kayombo \& Mlyakado, 2019). This new reality has fundamentally changed the way this generation thinks, conducts research, and communicates. It has become abundantly clear that integrating technology into our classrooms is essential to keep pace in our interconnected global economy and that students must have strong technology and media literacy as they enter the workforce (Ayere, Tirko, Onyango, \& Githui, 2010). Unfortunately, these fundamental changes in the way we communicate, find and share information, collaborate, and entertain ourselves have happened so quickly that educators and education leaders have found themselves struggling to keep up with the need for the rapid integration of computers into educational practice and the classroom (Knezek, Christensen, Hancock, \& Shoho, 2000).

The desire to integrate technology into the classroom to meet the demands of today's teachers and students has resulted in countless technology initiatives in schools around the world. It has quickly become clear, however, that simply buying a computer as hardware and distributing it to teachers and students is not enough to ensure the meaningful integration of computers into the classroom to enhance teaching and learning ( (Bariu, 2020; Kavagi, 2015; Kayombo \& Mlyakado, 2019). Because changes have happened so quickly and technology initiatives have been implemented so rapidly, our understanding of the barriers and opportunities for effective integration of computers into the classroom and the effect of such implementation on student achievement are still developing (Ngeze, 2017).

Computers in educational institutions are used frequently in performing administrative duties. For example, teachers may not use hand written student reports and deliver the same as large bundles of papers rather they could 
prepare computer reports and send them safely to parents and other stakeholders online (Hennessy, Ruthvet, \& Brindley, 2015). Computer can also be used in school setting for time tabling, preparation and management of students' data, and management of staff data, keeping schoolbooks of account, library resources management, stores management, secretarial services, preparation and management of examination results. Researchers in different parts of the world have identified the important role of computers in improving education (Obota, Oluoch, \& Makani, 2015).

In the international community, however, the status and importance of computers use in teaching and learning at school has been reported in various ways. The former UN General Secretary Koffi Annan (2005) as cited by Clement, Habibu, \& Abdullah-Al-Mamun(2018, p. 5)'computers are not a solution or magic formula, but they can improve the lives of everyone on this planet'. In fact, the participation of researchers and educators in the processes of change that computers bring to education is an opportunity to construct, shape and share developed knowledge. Educational system around the world are under increasing pressure to use the computers to teach students the knowledge and skills they need in the 21st century (Kavagi, 2015).

In Africa, computers are increasingly present in different countries and have been introduced to varying degrees at all educational levels from preschool to university, and in both formal and informal sectors (Ngeze, 2017). In East Africa particularly Kenya, the Ministry of Education and Technology (MOEST, 2005) discusses the ways in which computers can be applied to support and improve the delivery of quality education for all Kenyans. The MoEST(2015) says that there are obvious benefits for integrating computers into secondary schools as students at this age need to focus on subject specific contents, greater critical thinking skills, scientific inquiry and mathematics, science and language. Teachers will benefit greatly with the analytical, creative and collaborative power of computers to map out, analyze assumptions, present ideas, and participate in assessing students' progress and share experiences and ideas with peers from around the country and around the world (Ngeze, 2017).

In Tanzania, as reported by Swart and Wachira(2018), the situational analysis reveals that the government and the Ministry of Education recognize the potential of computers to act as a tool for improving education delivery, outcomes and impact, as evidenced through the national plans, policies and strategies. In recognizing the potential of computers as significant Information and communication Technology (ICT) tool for improving education system, the Government of Tanzania developed its national ICT policy in 2003 (URT, 2003, p. 3). Four years later, the Ministry of Education and Vocational Training (MoEVT), developed an ICT Policy for Basic Education in 2007. The Tanzania Vision 2025, the key national development strategy, also recognizes the role of computers as agent for transformation of the economy to a knowledge economy, and identifies the potential of computers to address most of the development challenges including those presented by education. The ICT policy for basic education of 2007 addresses issues related to use of computers in education institutions such as; infrastructure and technical issues; curriculum and content; training and capacity building; planning, procurement and administration; management and support; and monitoring and evaluation. The other objective was to facilitate and promote the use of computers in schools, colleges, and libraries (URT, 2007, p. 2). The integration of computers in basic education subsector is expected to yield several outcomes including the improved efficiency and effectiveness of the teaching and learning at all levels (URT, 2007, p. 4).

The Government of Tanzania through MoEST has implemented several programmes and initiatives that aim at implementing the ICT policy since it was developed in 2003. Such initiatives include National Programme on ICT for Secondary School Teachers, the e-Schools Project and the introduction of ICT Curriculum in secondary schools (Ndalichako \& Komba, 2018). These initiatives have contributed to the use of computers in teaching and learning and in performing school administrative tasks. However, in response to the national ICT policy for basic education, schools across the country had to navigate the new era that utilizes the computers infrastructure available in public schools to manage teaching and learning (Ndalichako \& Komba, 2018). A report by HakiElimu(2018) on analysis of implementation of ICT policy for basic education showed that the policy was yet to be adopted by many schools in Arusha city council. Thus study therefore investigated the Teachers' Use of computers in teaching and learning.

\subsection{Statement of the Problem}

Studies conducted in Tanzania (Mazoya, Ismail, \& Manyilizu, 2015; Ndalichako \& Komba, 2018; Ngeze, 2017) about computers integration in teaching and learning in secondary schools revealed that, the government has invested heavily on use of computers in education initiatives, including provision of computer skills and training to teachers and supply of computers and other ICT facilities in secondary school. Ngeze(2017, p. 425) added that, 'more efforts are ongoing by the government through the Ministry of Education, Science, and Technology (MoEST) to equip schools with computers, other ICT infrastructure and training'. Apart from these government initiatives to equip schools with computers and ICT infrastructures and training, teaching and learning in most secondary schools in Arusha City are done without the use computers (URT, 2020). Studies done in Arusha city council have focused in assessing availability and general uses of ICTs in public secondary schools, but have not specifically ascertain the extent of using computers for teaching and learning (Mandari, 2018; Zilpa, 2015; Majid, 2020). One common and important thing noticed in these studies is that, public secondary schools in Arusha city have computers for performing various tasks, but are not used in the teaching and learning process especially in classroom situations. Thus, this study investigated the Teachers' Use of computers in teaching and learning in public secondary schools in Arusha city council, Tanzania. The research question was, to what extent teachers use computers in teaching and learning in public secondary schools in Arusha city council?

\section{Significance of the Study}

The study's findings has shown to be useful information to public secondary schools, Education Officers at council level and other education stakeholders in Tanzania on Teachers' Use computers in teaching and learning. In relation to the 
education and training policy of 2014 as well as ICT policy for basic education of 2007, the study have exposed how teachers in secondary schools can make use of computers in improving to improve teaching and learning in public secondary schools. In addition, the study provided new insight to researchers and academicians for further research work that involves the integration of computers for teachers and administrators in secondary schools for improving teaching and learning. Lastly, this study have intensify the researcher's knowledge and understanding on conducting research and general knowledge on use of computers in education practices.

\section{Theoretical Framework}

This study was guided by Rogers' Diffusion of Innovation theories (Rogers, 1995) which argue that, teachers being initiators of innovations in teaching and learning play a key role of being change agents in diffusion of innovation process. In such a role, teachers are both, early adopters as well as promoters of the diffusion of the innovation in question (Rogers, 1995). Rogers' Diffusion of Innovation theories are of three types namely: the theory of innovation decision process; theory of individual innovativeness and the theory of the rate of adoption with time. In brief, the theory of innovation decision process describes a potential adopter as unconsciously going through five steps of experience. The steps include knowledge; persuasion; decision; implementation; and confirmation. The theory of Individual Innovativeness on its side, acknowledges the presence of distinct categories of adopters with different characteristics, which determine the readiness of an individual to adopt or reject an innovation. The third theory is the theory of the Rate of Adoption with Time. According to the theory, rate of adoption is a function of time. This study investigated factors limiting the use of computers in teaching and learning in secondary schools. Rogers' diffusion of innovation theories provides a better insight as to address adoption of new technology by teachers and its diffusion on the use of it in teaching and learning. Therefore, there is need to ensure that any proposed innovation such as the use of computers in teaching and learning, if it is to be successful, should start from an attempt to obtain the teachers' understanding, support and, indeed, approval. For a teacher to be competent, he or she must have proper teaching and learning skills for developing proper knowledge bases necessary for teaching.

\section{Literature Review}

Survey study by Wambura(2017) sought to explore teachers experience on the use computer to facilitate teaching in Ilala District primary schools, Tanzania, from the perspective of teachers. A sample of teachers were purposefully selected and were given questionnaires and then interviewed. The study mainly collected views and opinions from teachers regarding their experiences on the use of computer to facilitate teaching in schools. The study used mixed research approach and deployed descriptive survey in collecting data. The study found that to small extent primary school teachers in Ilala district use computer in teaching. The study identified teachers' positive attitude, teachers' competence in computer use, accessibility of computer facilities, professional development and availability of technical support being the factors that determine the teachers' use of computers in teaching. However, the study concentrated on gathering data only from teachers. Heads of schools and students are also important and key respondents on issues pertaining to the use of computers in both teaching and learning.

A study conducted by Milton (2018) investigated the effectiveness of integration of computers in pedagogy in contrast to conventional teaching. Both qualitative and quantitative methods were employed where by questionnaires and interviews were used. Findings showed that computer-related technologies change the teaching-learning process rapidly in school levels improving the student achievement and creating learning environments that are more interesting, effective and interactive. The study investigated the effectiveness of integration of computers in pedagogy not the use of computers in teaching and learning. This weakens to conclude to what extent teachers use computers in teaching and learning in schools.

A study conducted by Sangrà \& González(2014) investigated the role of computers in improving teaching and learning processes in primary and secondary schools in Galicia, Madrid, Valencia, the Basque Country and Catalonia in Spain. A multiple-case-study research methodology was applied using a mixed approach. The study found that computers in teaching favors several teaching and learning processes and that the improvement of teaching-learning processes is higher in schools that have integrated computers as an innovation factor. The author suggested that, to obtain maximum fruit of computer usage in education, there is a need for teachers to modernize the technological tools and change the teaching models, which proves that digital literacy plays an important role behind a successful teacher. The study explained the importance of computers in improving teaching-learning processes in schools that have integrated computers as an innovation factor, but the study did not analyzed to what are teachers use computers in teaching and learning.

A study by Bhalla(2016) examined computer use by school teachers in teaching-learning process in India. Mixed research approach was used and the study used constructed questionnaire that listed essential dimensions for teachers' use of computers: Computer Aided Learning (CAL), Computer Managed Instruction (CMI), and Computer Assisted Instruction (CAI). The findings revealed that teachers often use computers to update subject knowledge and teaching skills, develop lesson plans, prepare additional instructional material, notify relevant information via internet, and prepare question banks. Teachers sometimes used computers for showing something in the class, displaying students' work on school-website, preparing test papers, simulations, games, students' assignments. Findings depicted that teachers had either rarely or never used computers for presenting entire lesson, students' classroom presentations, tutorials, sharing information with parents, publishing homework, giving tests to students either offline or online, maintaining students records, and individualized instructions. The analysis indicated that amongst the three categories of computer use, CAL was the most popular category of computer use whereas CAI was the least popular among teachers. However, 
Bhalla(2016) study focused on examining computer use by school teachers in teaching-learning process in India, the current study investigated the extent of teachers use of computers in teaching and learning, with the experience of Arusha city council in Tanzania.

Kumari \& D'Souza (2016) conducted a study that aimed to find the Computer Literacy level of teacher's and the use of computer by teachers in teaching-learning process among Secondary Schools in Mangaluru Taluk, in Southwest India. Besides comparing the Computer Literacy of teachers and computer use in teaching-learning among Urban and Rural schools of Mangaluru Taluk, the study also aimed to find relationship between the two variables. Two questionnaires namely, Computer Literacy Inventory and computer Use in Teaching-Learning were administered to in-service secondary school teachers teaching Karnataka State Syllabus in various schools of Mangaluru Taluk. The findings revealed that the Computer literacy level of Secondary School teachers as well as the extent to which computer is used by teachers in Secondary Schools is average. There was no significant difference between both Computer Literacy and computer use of teachers in rural and urban schools. In addition, there exists positive relationship between Computer Literacy and computer use of teachers. The study concentrated in comparing computer literacy and computer use in teaching and learning by teachers in rural and urban schools. However, the study ignored other factors that could contribute to the use of computer in teaching and learning.

\section{Methodology}

Computers in public secondary schools in the study area establish the extent of use and how often teachers use computes in teaching and learning. The study was conducted in Arusha City Council in Arusha, Tanzania. The researcher chose Arusha city Council because preliminary studies conducted in the study area revealed the presence of computers in secondary schools and notified that such resources are not used in teaching and learning in most schools(Mandari, 2018; HakiElimu, 2018). Arusha City Council has 28 public secondary schools. The study involved ten (10) public secondary schools. Thus, there was a possibility of selecting schools and participants that were involved in the study. The target population were heads of schools and teachers. Teachers were involved because they are the ones who are involved in teaching on the daily routine basis in their schools. On the other hand, heads of schools were involved because they are the ones responsible to ensure teaching and learning activities are well organized and managed.

Applying a mixed research approach and a convergent parallel design, the first part of the study consisted of a self-administered questionnaire that delivered both quantitative data from teachers. The questionnaire consisted of predominantly closed questions, including varied response formats - Likert scale with various response choices. For the questionnaires, simple random sampling was used to get 100 teachers from ten (10) secondary schools (10 teachers from each school). The second part consisted of interview for heads of schools that delivered qualitative data. For the interview, ten (10) heads of schools were selected purposively because the researcher believes that they can provide in-depth information about the topic. During the process of data collection, the researcher conducted face-to-face interview with heads of secondary schools. The interview followed an open-ended format with the aim of understanding the extent of teachers' use of computers in teaching and learning from the perspective and experiences of the participants. The total sample size was 110 participants.

By respecting research ethics researcher, ensure approval for research clearance and permit were asked before embarking on data collection process. Of the 100 teachers approached, 100 returned their questionnaires, thus a response rate was $100 \%$. The quantitative data were analyzed for descriptive statistics of mean, standard deviation, frequencyand percentage. The qualitative data were analyzed thematically, which involved immersion in the data, checking familiarization, coding, interpretation and theme induction. Quantitative data were presented in form of tables while qualitative data were presented in form of tables and paraphrasing.

Precautions were taken to ensure trustworthiness of the qualitative data according to the criteria of credibility, applicability, dependability and confirmability(Creswell \& Creswell, 2018). These included peer debriefing to acknowledge and analyze personal preconceptions, biases and beliefs in the context of the research (Blanche \& Durrheim, 2011). A detailed audit trail that described exact steps followed in the research process ensured that the research could be replicated while triangulation of methods enhanced the trustworthiness of the study and triangulation of data ensured a correct understanding of the phenomenon (Creswell \& Creswell, 2018; Blanche \& Durrheim, 2011).

\section{Findings and Discussion}

This study was set to find out the availability of computers and related infrastructures and the extent to which teachers use computers in teaching and learning in public secondary schools in Arusha City council. Teachers filled questionnaires while heads of schools were interviewed through interview guide to give their comment about availability of computers and related infrastructures and the extent to which teachers use computers in teaching and learning. In addition, the researcher formulated an observation guide to confirm whether the heads of school comments and teachers' responses in questionnaire reflect what actually the reality is on ground. In filling out the questionnaires teachers were to put a tick to indicate their level of agreement in one of each item.

The first part in aimed to find out the availability of computers and other infrastructures in public secondary schools that are necessary for effective use of computers for teaching and learning. Teachers filled questionnaires to indicate the availability of computers and related infrastructures in their school. Findings from teachers' responses are presented in table 1. 


\begin{tabular}{|c|c|c|c|c|c|c|c|}
\hline \multirow{2}{*}{$\begin{array}{l}\text { Item } \\
\text { No. }\end{array}$} & \multirow{2}{*}{$\begin{array}{l}\text { Availability of Computer and Related } \\
\text { Infrastructures }\end{array}$} & \multicolumn{2}{|c|}{ Available } & \multicolumn{2}{|c|}{ Not Available } & \multicolumn{2}{|c|}{ Total } \\
\hline & & f & $\%$ & f & $\%$ & f & $\%$ \\
\hline A1 & Computers & 78 & 78.0 & 22 & 22.0 & 100 & 100.0 \\
\hline A2 & Electrical power & 95 & 95.0 & 5 & 5.0 & 100 & 100.0 \\
\hline A3 & Related programs & 55 & 55.0 & 45 & 45.0 & 100 & 100.0 \\
\hline A4 & Technical support & 45 & 45.0 & 55 & 55.0 & 100 & 100.0 \\
\hline A5 & $\begin{array}{c}\text { Supportive and auxiliary } \\
\text { infrastructures (e.g. internet, smart TV, } \\
\text { Projectors }\end{array}$ & 44 & 44.0 & 56 & 56.0 & 100 & 100.0 \\
\hline
\end{tabular}

Table 1: Teachers Responses on Availability of Computers and Related Infrastructures (N=100) Source: Field Data, 2021

Findings in Table 1 show that computers were rated as available by majority 78 (78.0\%) of teachers in the study area while only few $22(22.0 \%)$ teachers rated computers as not available in their schools. These findings were similar to those obtained by other researchers in the study area who asserted that, public secondary schools in Arusha city have computers for performing various tasks, but are not used in the teaching and learning process especially in classroom situations (Mandari, 2018; Zilpa, 2015; Majid, 2020). These findings indicate that computers are available in majority of public secondary schools in Arusha city council. For teachers to make use of computers for teaching and learnings computers should adequately be available at first place.

Apart from that, majority $95(95.0 \%)$ teachers rated electrical power to be available in their schools while only 5 $(5.0 \%)$ rated electrical power as not available in their schools. These findings imply that electricity was available in most public secondary schools in the study area. It was necessary to ascertain the availability of electrical power since computers could not be of use in teaching and learning without electricity.

The item related programs was rated available by $55(55.0 \%)$ teachers while $45(45.0 \%)$ rated related programs as not available. These findings indicated that at least half of the available computers found in public secondary schools are installed with related programs that enables the use of computers in teaching and learning. Programs related to teaching and learning are necessary for realizing the use of computers in teaching and learning (Ngeze, 2017).

Findings in table 1 also indicated that technical support was rated available by 45 (45.0\%) of respondents while $55(55.0 \%)$ respondents rated technical support to be not available in their schools. These findings were also observed by Clement, et al. (2018) who found that, among major barriers in using computers for teaching and learning were lack of proper training skills, unavailability of lack of expert technical staff and poor administrative support. This means almost half of schools surveyed in the study area have no technical support for assisting various technical problems that relate to the use of computers in the teaching and learning.

Additionally, 56 (56.0\%) participants rated supportive and auxiliary infrastructures available, and 44 (44.0\%) participants as not available. This means that in majority of surveyed schools, supportive and auxiliary infrastructures were not available. These infrastructures are necessary to be available in public secondary schools as they are used along with computers in facilitating teaching and learning activities.

The researcher conducted a non-participant observation using observation guide to supplement findings obtained from teachers' responses. During observation, the researcher used an observation guide to check the availability of computers and other infrastructures as well as to approve the availability of computers in departments and offices around the school. Data collected from the field are presented in table 2.

\begin{tabular}{|c|c|c|c|c|c|c|c|}
\hline Item No. & $\begin{array}{c}\text { Availability of Computer and } \\
\text { Infrastructures }\end{array}$ & \multicolumn{2}{|c|}{ Available } & \multicolumn{2}{|c|}{ Not available } & \multicolumn{2}{c|}{ Total } \\
\cline { 3 - 8 } & f & $\mathbf{\%}$ & $\mathbf{f}$ & $\mathbf{\%}$ & $\mathbf{f}$ & $\mathbf{\%}$ \\
\hline 1 & Computers & 10 & 100 & 0 & 0.0 & 10 & 100.0 \\
\hline 2 & Electrical power & 10 & 100 & 0 & 0.0 & 10 & 100.0 \\
\hline 3 & Related programs & 7 & 70.0 & 3 & 30.0 & 10 & 100.0 \\
\hline 4 & Technical support & 5 & 50.0 & 5 & 50.0 & 10 & 100.0 \\
\hline 5 & $\begin{array}{c}\text { Supportive and auxiliary } \\
\text { infrastructures (e.g. internet, smart } \\
\text { TV, Projectors) }\end{array}$ & 5 & 50.0 & 5 & 50.0 & 10 & 100.0 \\
\hline
\end{tabular}

Table 2: Researcher Observation Findings on Availability of Computers and

Infrastructures in Secondary Schools

Source: Field Data, 2021

As presented in table 2 findings show that computers and electrical power are available in all 10 (100\%) surveyed public secondary schools. this means that computers can be used at school for various purposes including teaching and learning, since they are available and there is electrical power. Furthermore, majority 7 (70.0\%) of the surveyed schools had related programs in the available computers that can be used for teaching and learning. Technical support as well as 
supportive and auxiliary infrastructures (e.g. internet, smart TV, Projectors) were found to be averagely available, since findings show that they were available in 5 (50.0\%) schools out of 10 in the study area.

The second part in teachers' questionnaire was set to elicit participants' extents of using computers in teaching and learning. In filling out the questionnaires teachers were to put a tick to indicate their level of agreement in one of each item on the extent they use computers in teaching and learning in their schools. The questionnaires were prepared having five point Likert scale range from Very Large Extent $(=5)$ to Very Small Extent $(=1)$. Mean and standard deviation were used to determine the average of respondents' responses. Within the five point ranges, three trisecting scores were used to make the analysis clear as suggested by Creswell \& Creswell(2018); these scores were 2.49, 3.49 and 4.49. Thus, the extent of teachers use of computers in teaching and learning were analyzed based on the responses of the respondents. The Remark was reached upon the mean value, where by a mean value from $\leq 1.49$ were To a Very Small Extent, 1.5 to 2.49 were Small Extent, from 2.5 to 3.49 were Moderate Extent, from 3.50 to 4.49 were Large Extent, and from 4.50 to 5.00 were Very large Extent. Data collected from the respondents are presented in table 3.

\begin{tabular}{|c|c|c|c|c|c|c|c|c|c|}
\hline \multirow[t]{2}{*}{$\begin{array}{c}\text { Item } \\
\text { No. }\end{array}$} & \multirow{2}{*}{$\begin{array}{l}\text { To what extent } \\
\text { you use } \\
\text { computers in the } \\
\text { following } \\
\text { activities. }\end{array}$} & VSE & SE & ME & LE & VLE & \multirow[t]{2}{*}{$\mathbf{M}$} & \multirow[t]{2}{*}{ SD } & \multirow[t]{2}{*}{ Remark } \\
\hline & & $\begin{array}{c}f \\
(\%)\end{array}$ & $\begin{array}{c}f \\
(\%)\end{array}$ & $\begin{array}{c}\mathrm{f} \\
(\%)\end{array}$ & $\begin{array}{c}f \\
(\%)\end{array}$ & $\begin{array}{c}\text { f } \\
(\%)\end{array}$ & & & \\
\hline B6 & $\begin{array}{l}\text { Planning for } \\
\text { teaching }\end{array}$ & $\begin{array}{c}33 \\
(33.0) \\
\end{array}$ & $\begin{array}{c}21 \\
(21.0)\end{array}$ & $\begin{array}{c}31 \\
(31.0) \\
\end{array}$ & $7(7.0)$ & $8(8.0)$ & 2.36 & 1.24 & $\begin{array}{c}\text { To a Small } \\
\text { Extent }\end{array}$ \\
\hline B7 & $\begin{array}{c}\text { Lesson } \\
\text { preparation }\end{array}$ & $\begin{array}{c}40 \\
(40.0) \\
\end{array}$ & $\begin{array}{c}18 \\
(18.0) \\
\end{array}$ & $\begin{array}{c}17 \\
(17.0)\end{array}$ & $\begin{array}{c}17 \\
(17.0)\end{array}$ & $8(8.0)$ & 2.35 & 1.37 & $\begin{array}{c}\text { To a Small } \\
\text { Extent }\end{array}$ \\
\hline B8 & $\begin{array}{c}\text { Lesson } \\
\text { presentation }\end{array}$ & $\begin{array}{c}39 \\
(39.0)\end{array}$ & $\begin{array}{c}25 \\
(25.0)\end{array}$ & $\begin{array}{c}18 \\
(18.0)\end{array}$ & $8(8.0)$ & $\begin{array}{c}10 \\
(10.0)\end{array}$ & 2.25 & 1.32 & $\begin{array}{l}\text { To a Small } \\
\text { Extent }\end{array}$ \\
\hline B9 & $\begin{array}{c}\text { Assessment and } \\
\text { evaluation }\end{array}$ & $\begin{array}{c}29 \\
(29.0)\end{array}$ & $\begin{array}{c}17 \\
(17.0)\end{array}$ & $\begin{array}{c}11 \\
(11.0)\end{array}$ & $\begin{array}{c}25 \\
(25.0)\end{array}$ & $\begin{array}{c}18 \\
(18.0)\end{array}$ & 2.86 & 1.52 & $\begin{array}{c}\text { To a Small } \\
\text { Extent }\end{array}$ \\
\hline B10 & Record keeping & $8(8.0)$ & $\begin{array}{c}16 \\
(16.0)\end{array}$ & $\begin{array}{c}17 \\
(17.0)\end{array}$ & $\begin{array}{c}33 \\
(33.0)\end{array}$ & $\begin{array}{c}26 \\
(26.0)\end{array}$ & 3.53 & 1.26 & $\begin{array}{c}\text { To a } \\
\text { moderate } \\
\text { Extent }\end{array}$ \\
\hline B11 & $\begin{array}{c}\text { Communication } \\
\text { and Information } \\
\text { sharing }\end{array}$ & $\begin{array}{c}13 \\
(13.0)\end{array}$ & $\begin{array}{c}37 \\
(37.0)\end{array}$ & $\begin{array}{c}13 \\
(13.0)\end{array}$ & $\begin{array}{c}20 \\
(20.0)\end{array}$ & $\begin{array}{c}17 \\
(17.0)\end{array}$ & 2.49 & 1.33 & $\begin{array}{l}\text { To a Small } \\
\text { Extent }\end{array}$ \\
\hline
\end{tabular}

Table 3: Teachers Responses on the Extent They Use Computers in Teaching and Learning Source: Field Data, 2021

Key: $V S E=$ Very Small Extent, $S E=$ Small Extent, $M E=$ Moderate Extent, $L E=$ Large Extent,$V L E=$ Very Large Extent,$M=$ Mean,$S D=$ Standard Deviation

Table 3 indicates that, teachers uses computers to a small extent in Planning for teaching ( $M=2.36, S D=1.24)$, lesson preparation $(M=2.35, S D=1.37)$, lesson presentation $(M=2.25, S D=1.32)$, assessment and evaluation $(\mathrm{M}=2.86, \mathrm{SD}=1.52)$ and in communication and Information sharing $(\mathrm{M}=2.49, \mathrm{SD}=1.33)$. However, findings revealed that teachers uses computers to a moderate extent in record keeping $(M=3.53, S D=1.26)$. These findings were also observed by Bhalla (2016) when examined computer use by school teachers in teaching-learning process in India, and found that teachers had either rarely or never used computers for presenting entire lesson, students' classroom presentations, tutorials, sharing information with parents, publishing homework, giving tests to students either offline or online, maintaining students records, and individualized instructions. This imply that, computers are available in public secondary schools in the study are used to a small extent in planning for teaching, lesson preparation, lesson presentation, assessment and evaluation and in communication and information sharing. Teachers use computers to moderate extent for record keeping. In most schools computers are used to keep students' academic records such as examination and test scores as well as students registration records.

The third part in teachers' questionnaire was set to bring about how often teachers use computers in teaching and learning. In filling out the questionnaires teachers were to put a tick to indicate their level of agreement in one of each item on how often they use computers in teaching and learning in their schools. The questionnaires were prepared having five point Likert scale range from Very often $(=5)$ to Not at All $(=1)$. Mean and standard deviation were used to determine the average of respondents' responses. Within the five point ranges, three trisecting scores were used to make the analysis clear as suggested by Creswell \& Creswell(2018); these scores were 2.49, 3.49 and 4.49. Thus, the often of teachers use of computers in teaching and learning were analyzed based on the responses of the respondents. The Remark was reached upon the mean value, where by a mean value from $\leq 1.49$ were Not at All, 1.5 to 2.49 were rarely, from 2.5 to 3.49 were less often, from 3.50 to 4.49 were Often, and from 4.50 to 5.00 were very often. Data collected from the respondents are presented in table 4. 


\begin{tabular}{|c|c|c|c|c|c|c|c|c|c|}
\hline \multirow{2}{*}{$\begin{array}{l}\text { Item } \\
\text { No. }\end{array}$} & \multirow{2}{*}{$\begin{array}{l}\text { How often you use } \\
\text { computers in the } \\
\text { following activities. }\end{array}$} & NA & $\mathbf{R}$ & LO & $\mathbf{0}$ & VO & \multirow[t]{2}{*}{$\mathbf{M}$} & \multirow[t]{2}{*}{ SD } & \multirow[t]{2}{*}{ Remark } \\
\hline & & $\begin{array}{c}f \\
(\%)\end{array}$ & $\begin{array}{c}f \\
(\%)\end{array}$ & $\begin{array}{c}\text { f } \\
(\%)\end{array}$ & $\begin{array}{c}f \\
(\%)\end{array}$ & $\begin{array}{c}f \\
(\%)\end{array}$ & & & \\
\hline B12 & $\begin{array}{l}\text { Planning for } \\
\text { teaching }\end{array}$ & $\begin{array}{c}31 \\
(31.0)\end{array}$ & $\begin{array}{c}24 \\
(24.0)\end{array}$ & $\begin{array}{c}18 \\
(18.0)\end{array}$ & $\begin{array}{c}16 \\
(16.0)\end{array}$ & $\begin{array}{c}11 \\
(11.0)\end{array}$ & 2.42 & 1.37 & Rarely \\
\hline B13 & Lesson preparation & $\begin{array}{c}26 \\
(26.0)\end{array}$ & $\begin{array}{c}25 \\
(25.0)\end{array}$ & $\begin{array}{c}23 \\
(23.0)\end{array}$ & $\begin{array}{c}23 \\
(23.0)\end{array}$ & $3(3.0)$ & 2.41 & 1.19 & Rarely \\
\hline B14 & Lesson presentation & $\begin{array}{c}34 \\
(34.0)\end{array}$ & $\begin{array}{c}25 \\
(25.0)\end{array}$ & $\begin{array}{c}16 \\
(16.0)\end{array}$ & $\begin{array}{c}18 \\
(18.0)\end{array}$ & $7(7.0)$ & 2.39 & 1.31 & Rarely \\
\hline B15 & $\begin{array}{c}\text { Assessment and } \\
\text { evaluation }\end{array}$ & $\begin{array}{c}17 \\
(17.0) \\
\end{array}$ & $\begin{array}{c}24 \\
(24.0) \\
\end{array}$ & $\begin{array}{c}17 \\
(17.0) \\
\end{array}$ & $\begin{array}{c}25 \\
(25.0) \\
\end{array}$ & $\begin{array}{c}17 \\
(17.0) \\
\end{array}$ & 3.01 & 1.37 & $\begin{array}{l}\text { Less } \\
\text { Often }\end{array}$ \\
\hline B16 & Record keeping & $\begin{array}{c}9 \\
(9.0)\end{array}$ & $\begin{array}{c}14 \\
(14.0)\end{array}$ & $\begin{array}{c}13 \\
(13.0)\end{array}$ & $\begin{array}{c}36 \\
(36.0)\end{array}$ & $\begin{array}{c}28 \\
(28.0)\end{array}$ & 3.6 & 1.28 & $\begin{array}{l}\text { Less } \\
\text { Often }\end{array}$ \\
\hline B17 & $\begin{array}{l}\text { Communication and } \\
\text { Information sharing }\end{array}$ & $\begin{array}{c}13 \\
(13.0)\end{array}$ & $\begin{array}{c}39 \\
(39.0)\end{array}$ & $\begin{array}{c}12 \\
(12.0)\end{array}$ & $\begin{array}{c}20 \\
(20.0)\end{array}$ & $\begin{array}{c}16 \\
(16.0)\end{array}$ & 2.47 & 1.32 & Rarely \\
\hline
\end{tabular}

Table 4: Teachers Responses on How Often They Use Computers in Teaching and Learning Source: Field Data, 2021

Key: VO = Very Often, $O=$ Often, $L O=$ Less Often, $R=$ Rarely, $N A=$ Not At All, $M=$ Mean, $S D=$ Standard Deviation

Table 4 indicates that, teachers use computers rarely in planning for teaching $(M=2.42, S D=1.367)$, lesson preparation $(M=2.41, S D=1.19)$, lesson presentation $(M=2.39, S D=1.31)$ and in communication and information sharing $(\mathrm{M}=2.47, \mathrm{SD}=1.32)$. It was further revealed that teachers use computers less often in assessment and evaluation (M=3.01, $\mathrm{SD}=1.37)$ as well as in record keeping $(\mathrm{M}=3.6, \mathrm{SD}=1.279)$. These findings imply that computers available in public secondary schools in the study are rarely used in planning for teaching, lesson preparation, lesson presentation and in communication and information sharing. At least teachers in the study area use computers in assessment and evaluation and in record keeping but less often.

The study conducted interview with heads of schools on the extent to which teachers use computers in teaching and learning. Participants responded to the interview guide for heads of school through face-to-face interview. Their responses were thematically analyzed and the summary of the analysis are presented in Figure 1 and Table 5 respectively. Respondents were asked, 'Does your school have Computers that can be used by teachers in teaching and learning?' Their responses are presented in figure 1.

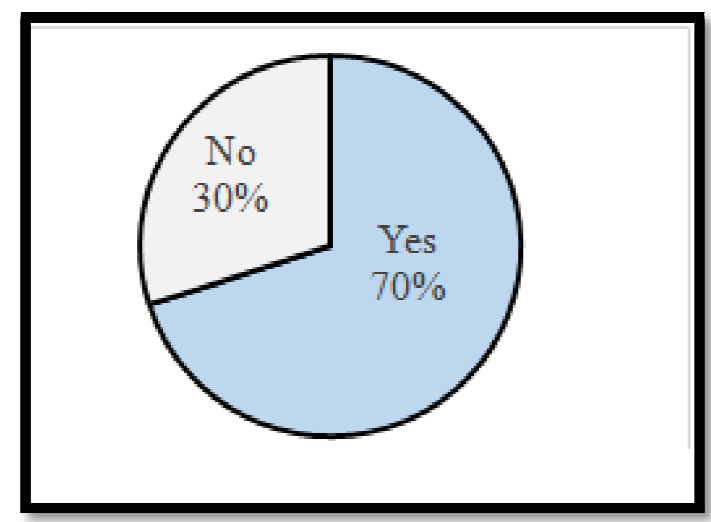

Figure 1: Heads of Schools Comment on Availability of Computers in Their Schools Source: Field Interview 2021

As depicted in figure 1, findings show that majority (70\%) of participants said'YES', for thus their schools have computers that can be used by teachers in teaching and learning. These findings imply that, computers are available in secondary schools in Arusha city council and teachers can use them in teaching and learning.

Another question for heads of school's interview asked respondents to 'Comment about the teachers' use of computers in teaching and learning'. Heads of school opinions were analyzed thematically and the summary of the findings are presented in table 5 . 


\begin{tabular}{|c|c|c|}
\hline Comments on the Teachers' Use of Computers in Teaching & \multicolumn{2}{|c|}{ Heads of Schools } \\
\cline { 2 - 3 } and Learning & $\mathbf{X / 1 0}$ & Percent (\%) \\
\hline $\begin{array}{c}\text { Computers are used rarely together with projector for } \\
\text { displaying teaching media (materials) especially in science } \\
\text { subjects }\end{array}$ & 6 & $60.0 \%$ \\
\hline $\begin{array}{c}\text { Few teachers use computers in preparation of lesson notes and } \\
\text { preparing schemes of work }\end{array}$ & 7 & $70.0 \%$ \\
\hline $\begin{array}{c}\text { Computers are used in keeping students records, grading } \\
\text { students' scores and in assessing students learning. }\end{array}$ & 8 & $80.0 \%$ \\
\hline $\begin{array}{c}\text { Teachers use computers for searching teaching material and } \\
\text { media online and use them for teaching in class }\end{array}$ & 6 & $60.0 \%$ \\
\hline
\end{tabular}

Table 5: Heads of Schools Opinions on Teachers' Use of Computers in Teaching and Learning Source: Field data, 2021

Findings in table 5 indicate that majority 6 (60\%) participants commented that computers are used rarely together with projector for displaying teaching media (materials) especially in science subjects. One head of school commented that:

'...most of my teachers use computers and projectors in teaching and learning. ... They also make use of computer in different ways here, for example they use their laptop and school projector in class for showing different models and displaying various science related concepts'

Source: Field interview 2021

Not only that, but also 7 (70\%) participants argued that few teachers use computers in preparation of lesson notes and preparing schemes of work, and 8 (80\%) argued that computers are used in keeping students records, grading students' scores and in assessing students learning. Among the comments, one head of school insisted that:

... We use computers in various activities in our school, speaking of teaching and learning my teachers use computers to keep students records as well as to simplify assessment of students by grading them accurately'

Source: Field interview 2021

Findings in Table 5 also revealed that, 6 (60\%) participants mentioned that teachers use computers for searching teaching material and media online and use them for teaching in class. One head of school commented that:

'Okay! Because we have computer lab in our school, I have seen most of my teachers use computer to search teaching material when they prepare themselves for classroom teaching. In my school, teachers also use school internet to download teaching media online and use them in teaching'

Source: Field interview 2021

Similar findings were also obtained by Bhalla (2016) when examined computer use by school teachers in teaching-learning process in India and found that teachers sometimes used computers for showing something in the class, displaying students' work on the screen, preparing test papers, simulations, and in demonstrations.

To sum up, the study aimed to elicit answers from respondents about the extent of teachers' use of computers in teaching and learning in public secondary schools in Arusha City Council. Regarding the availability of computers and other related infrastructures, findings for this study have gathered that computers, electrical power and related programs were found to be available in public secondary schools in the study area. Moreover, technical support as well as supportive and auxiliary infrastructures were found to be averagely available and not available in other schools. With regard to the extent of using computers in teaching and learning, finding gathered that, computers are used to a small extent in planning for teaching, lesson preparation, lesson presentation, assessment and evaluation and in communication and information sharing. Nevertheless, to moderate extent teachers use computers for record keeping. Regarding to how often teachers use computers in teaching and learning, finding exposed that, teachers less often use computers in assessment and evaluation and in record keeping but rarely in planning for teaching, lesson preparation, lesson presentation as well as in communication and information sharing.

\section{Conclusions and Recommendations}

Based on the findings of the current study, the following conclusions were drawn:

- The result of the study revealed that computers, electrical power and related programs were available in public secondary schools in the study area. However, technical support, supportive and auxiliary infrastructures were averagely available and not available in other schools. The extent of using computers in teaching and learning found to be small in planning for teaching, lesson preparation, lesson presentation, assessment and evaluation as well as in communication and information sharing but to a moderate extent teachers use computers for record keeping. Thus, it is possible to conclude that, although computers, electrical power and related programs are available, teachers in public secondary schools use computers for teaching and learning in small extent.

- According to the findings of the current study, discussions and conclusions, this study put forward the following recommendations for immediate effect and for further studies

- Management in Secondary schools should come up with practical strategies to ensure teachers make use and integrate computers to simplify and improve effectiveness in education delivery.

- The government should ensure availability of computers and adequate supportive infrastructure in secondary schools to enhance the use of computers in teaching and learning. 
- The government should ensure trainings of teachers through workshops and seminars to enhance their knowledge and skills in using computer as tools to improve effectiveness in teaching and learning.

- Several issues requiring further investigation emerged from this research study. Therefore, the following recommendation are posted for further studies.

- This study was based in Arusha city council and employed mixed research approach. Consequently, it will be difficult to generalize the findings to other areas because the sample was drawn from Arusha city council only and from ten schools only. Therefore, another study should be conducted with comparison approach to the extent of teachers' use of computers in teaching and learning in public secondary schools using wider area and large sample than what was used in this study.

- Since the study was conducted in public secondary schools only, it is recommended that, a similar study to be conducted on the same topic while comparing extent of teachers' use of computers in teaching and learning in public and in private secondary schools.

\section{References}

i. Ayere, M. A., Tirko, R., Onyango, J., \&Githui, T. (2010). E-Learning in Secondary Schools in Kenya: A case of NEPAD E-schools. Kenya: Maseno University. Retrieved from http://www.academicjournals.org/ERR2

ii. Bariu, T. N. (2020). Status of ICT Infrastructure Used in Teaching and Learning in Secondary Schools in Meru County, Kenya. European Journal of Interactive Multimedia and Education, 1(1), 1- 8. Retrieved from https://doi.org/10.30935/ejimed/8283

iii. Bhalla, J. (2016). Computer Use by School Teachers in Teaching-learning Process. Journal of Education and Training Studies, I(2), 174-185.

iv. Blanche, T., \&Durrheim, K. (2011). Interpretive Methods. Research in practice: Applied methods for the social sciences. (B. M. Terre, \& K. Durrheim, Eds.) Cape Town: University of Cape Town Press.

v. Clement, C., Habibu, P., \& Abdullah-Al-Mamun, M. (2018). Difficulties Faced by Teachers in Using ICT in TeachingLearning at Technical and Higher Educational Institutions of Uganda. International Journal of Engineering Research \& Technology (IJERT), 3(7), 1-9.

vi. Creswell, J. W., \& Creswell, J. D. (2018). Research Designs: Qualitative, Quantitative and Mixed Methods Approaches. 5th Edition. Los Angeles: SAGE Publication, Inc.

vii. HakiElimu. (2018). The Impact of the Implementation of Fee-Free Education Policy on Basic Education in Tanzania: A Qualitative Study. Dar es salaam: HakiElimu.

viii. Hennessy, S., Ruthvet, K., \& Brindley, S. (2015). Teacher perspectives on integrating ICT into subject teaching: commitment, constraints, caution, and change. Journal of Curriculum Studies, XXXVII(2), 155-192.

ix. Kavagi, L. (2015). The use of Computers in Secondary School: A Survey of Schools in Western Province. Nairobi: Unpublished Thesis. Moi University.

x. Kayombo, J. J., \&Mlyakado, B. P. (2019, April). The paradox of ICT integration in secondary education in Tanzania: Assessment of teachers' ICT knowledge and skills in Tanga and Mwanza regions. International Journal of Research Studies in Educational Technology, 5(1), 17-27. doi:10.5861/ijrset.2015.1299

xi. Knezek, G., Christensen, R., Hancock, R., \&Shoho, A. (2000). Toward a Structural Model of Technology Integration. Hawaii Educational Research Association Annual Conference (pp. 1-48). Honolulu: HI.

xii. Kumari, N. V., \& D'Souza, F. (2016). International Journal of ComputationalResearch and Development, I(1), 114146.

xiii. Majid, I. (2020). ICT in Education: A Backbone for Teaching and Learning Process in Arusha City. United International Journal for Research \& Technology, 1(3), 2582-6832.

xiv. Mandari, K. V. (2018). ICT Literacy among Teachers and Administrators in Secondary Schools towards Effective Management of Students' Academic Records in Tanzania - The Case of Arusha City Council. International Journal of Science and Research (IJSR), 7(12), 974 - 979. doi:10.21275/ART20193703

xv. Mazoya, A., Ismail, A., \&Manyilizu, M. (2015). Age of Teachers Vs ICT use in Tanzanian Secondary Schools: A Case of Dodoma Municipality. Journal of Computer Applications- 132 (14), 173 - 177.

xvi. Milton, V. (2018). Digital literacy and digital pedagogies for teaching literacy: Pre-service teachers' experience on teaching rounds. Journal of Literacy and Technology, XIV(1), 72-97.

xvii. MoEST. (2015). Kenya Education Sector Support Programme 2015-2020; Delivering Quality Education and Training to all Kenyans. Government Printers: Nairobi. Retrieved from www.education.go.ke

xviii. Ndalichako, J. L., \&Komba, A. A. (2018). Students' Subject Choice in Secondary Schools in Tanzania: A Matter of Students' Ability and Interests or Forced Circumstances? Open Journal of Social Sciences, 2(1), 49-56.

xix. Ngeze, V. L. (2017). ICT Integration in Teaching and Learning in Secondary Schools in Tanzania: Readiness and Way Forward. International Journal of Information and Education Technology, 7(6), 424 -427.

xx. Obota, B. N., Oluoch, S. E., \&Makani, L. (2015). An Assessment of the Availability of ICT Infrastructure for Curriculum Instruction in Public Secondary Schools in Mumias Sub-County, Kenya. Journal of Research \& Method in Education (IOSR-JRME), V(1), 52-57.

xxi. Sangrà, A., \& González, M. S. (2014). The role of information and communication technologies in improving teaching and learning processes in primary and secondary schools. Research in Learning Technology, XVIII(3), 207-220. doi:10.1080/09687769.2010.529108

xxii. Swarts, P., \&Wachira, E. W. (2018). Tanzania: ICT In Education Situational Analysis Report. Global e-Schools Community Innitiatives, 1-67. 
xxiii. URT. (2003). National information and Communication Technologies Policy. Dar es Salaam: Ministry of Communicationand Transport.

xxiv. URT. (2007). Information and Communication Technologies Policy for Basic Education. Dar es Salaam: Ministry of Education and Vocational Training.

xxv. URT. (2020). Northern Zone Inspectorate Reports 2019. Arusha: Regional Commissioners office-Arusha.

xxvi. Wambura, C. (2017). The Extent of Computer Usage Among School Teachers and Students in Ilala Municipality, Dar es Salaam. Unpublished Master Dissertation: Open University of Tanzania.

xxvii. Zilpa, G. O. (2015). Effectiveness of Teaching Computer Studies Subject in Secondary Schools in Tanzania: A Case of Arusha Municipality. Unpublished Masters Dissertation: Mzumbe University. 